\title{
Water Supply Services to Cities in Spain and the Debate on Private Participation in Their Management: Which Is More Efficient? ${ }^{1}$
}

\author{
Martín Sevilla \\ University of Alicante \\ Teresa Torregrosa \\ University of Alicante \\ José Francisco Perles \\ University of Alicante
}

\begin{abstract}
The supply of water to towns is one of the fundamental services of any municipality in Spain, given the importance of the asset it is intended to manage, regardless of the form in which its provision is chosen. However, this is not always the case, and sometimes it is seen more as a source of extra funding for the municipality and a matter of political discussion on the convenience of one or another form of management: public or private.

Currently in Spain, 45\% is public management and 55\% is totally or partially with private participation. In this paper we have analyzed, through their Annual Accounts (Accounts (Operating Accounts and Balance Sheet filed with the Mercantile Registry or data provided to the Ministry of Finance), the companies operating in the main Spanish cities, trying to determine the role played by private participation in the management of mixed companies to gain a better understanding of this important economic and social sector.
\end{abstract}

Keywords: joint venture, public company, water supply, annual accounts, expenses and revenues

\section{INTRODUCTION}

The public provision of certain services is justified by the essential nature of the activity. Article 128.2 of the Spanish Constitution establishes that "public initiative in economic activity is recognized. By law, essential resources or services may be reserved to the public sector, especially in the case of monopolies [...]". And the urban water supply service, of municipal competence, according to Law 7/1985 Regulating the Bases of the Local Regime of 1985, is one of them. In addition, the law also provides for the different modalities through which these services can be provided. These range from direct management by the municipality itself, public entities or companies, to public-private partnership formulas that enable the establishment of synergies between the Administration and companies. In Spain, according to the most recent data, $35 \%$ of the population is supplied by public entities, $33 \%$ by private companies, $22 \%$ by mixed 
companies and the remaining $10 \%$ by municipal services (AEAS, 2018). In other words, 55\% of the population receives water through companies wholly or partially owned by private capital that have obtained the corresponding concessions and the rest does so through purely municipal companies or by direct management by the municipalities themselves.

The aim of this paper is to analyze private action in the management of urban water supply services, through its participation in joint supply service companies. For this purpose, we will compare the accounting data from the profit and loss accounts and balance sheets of public ${ }^{2}$ and mixed companies, trying to determine the relevance of private capital in the performance of their activities.

\section{PRIVATE PARTICIPATION IN WATER SUPPLY SERVICES}

The involvement of private firms in the provision of public services has been widely documented in numerous works from different fields (Hodge and Greve, 2018, Moore et al., 2017; Devkar et al., 2013; The World Bank, 2012; Hodge et al., 2012, Wollmann \& Marcou, 2010; Willig, 1993). Ridau (2012), from a perspective.

The report, which is critical, establishes public-private partnerships (PPPs) as an alternative tool to traditional bidding, which can not only maintain a steady pace of contracting for works that require major planning and financing needs, but also have a lower impact in terms of public accounting, thanks to the treatment given to non-public assets. In addition, CPP makes it possible to maintain a significant volume of public works business, with a relatively lower financial effort, optimizing economic flows through the capture of private assets but without ruling out vigorous public intervention in many cases (Rebollo, 2007). Services such as electricity (Lee et al., 2019; Vagliasindi, 2013, Hall and Lobina, 2004), health (Ferrerira and Marques, 2020; Comendeiro-Maaløe et al., 2019; Mckee et al., 2006), infrastructure (Sánchez-Gomez and López Parra, 2017; Hammami et al., 1999), or water supply services (Peda and Vinnari, 2020; Bel, 2020, Ameyaw, et al. 2017; Jensen, 2017; Ruiz-Villaverde and García-Rubio, 2017, Schouter and Van Dijk, 2008), are some of those that traditionally have significant private sector participation in their provision. The latest Report on Private Participation in Infrastructure prepared by the World Bank (The World Bank, 2020) is along the same lines.

But not only private participation is the subject of analysis, but also the preference for any of the different models of service provision per se, -concession to private companies, provision through public companies or public-private partnership through joint ventures-, although these analyses are not globally conclusive (Marques and Simões, 2020, Boggio, 2016; Romano and Guerrini, 2011; González-Gómez et al. 2010, Bel \& Warner, 2008; Dassler et al., 2006; Kirkpatrick et al., 2006; Estache \& Rossi, 2002; Braadbaart, 2002; Thanassoulis, 2000). Arbués et al., (2017) or Sanaú (2017) bet on the superiority of the concession model in the provision of the service, based on the economic efficiency it provides, trying with these contributions to dismantle the "myth" of the alleged advantages of "remunicipalization". Among these supposed advantages would be the tariff reductions (González-Gómez \& García-Rubio, 2018 ; Troesken, 2001), which according to Bel (2020) would not always be sustainable over time. Suárez-Varela et al., (2016) conclude that private management is more efficient in the use of labor input, mainly due to technological restrictions faced by public management such as legal and institutional restrictions and that private management seems to be less efficient in the management of operating costs. Lobina (2013) for his part suggests that institutional adaptability explains the efficiency and effectiveness of the public sector relative to the private sector. Frone and Frone (2013) show several successful models of PPPs used to manage and mitigate risks and improve performance in the delivery of public water supply and sanitation services. Voorn et al., (2017) argue that municipally owned corporations do provide a viable means of delivering some local public services, including water management, and are capable of initiating and managing complex contracts.

In line with other works, González-Gómez et al. (2010) argue that the economic literature has not been able to demonstrate that private management is more efficient than public management, so there must be other reasons that lead governments to privatize the service. On the contrary, concerns about excessive prices and corruption in private management emerge as the factors that most influence remunicipalization, while ideological pressures seem to play a much less relevant role (Bel, 2020). 
In Spain there is a long tradition in the creation of joint ventures that carry out a peculiar model of public-private collaboration. While the resulting company is of mixed capital, and its governing bodies reproduce this participation, the operational management is carried out exclusively by the private partner, with the public partner having a token participation in this area.

There is no doubt that an adequate provision of water and sanitation services for citizens, while requiring that such services be provided as an essential priority by public officials, also requires enormous amounts of resources for their implementation, both in terms of investments in infrastructure and in current expenses for their maintenance (OHCHR, 2011). The great financial shortcomings of the public sector, the poor organization of its finances and the lack of financing for long-term infrastructure investments, with very long amortization periods for the same, have led some international organizations to seek alternatives (THE WORLD BANK, (2020). In an issue as relevant as the human right to drinking water and sanitation, the United Nations, in the 2030 Agenda for sustainable development, establishes in its objective number 17 that it is necessary to encourage and promote the formation of public and public-private partnerships to facilitate the achievement of the 2030 SDGs.

But apart from these questions, the discussion that has arisen is also related to the different efficiency and results between one or the other option, both from the private and the public point of view, and to what extent which of them is the most advantageous and for whom.

We have tried to see the main differences between these models through the information available from the data of the Mercantile Registry and the Ministry of Finance.

\section{THE SAMPLE / THE DATA}

It is important to highlight the problems surrounding the collection of data related to public utilities in general, and water utilities in particular. Theoretically, under the provisions of Articles 1, 2 and 3, of Law $27 / 2006$, of July 18 , regulating the rights of access to information, public participation and access to justice in environmental matters (incorporating Directives 2003/4/EC and 2003/35/EC), and in accordance with the provisions of Law 19/2013, of December 9, on transparency, access to public information and good governance, access to the economic data of companies that are in some way participated with public capital, should be available. But this is not always the case. After requests to the companies and city councils, directly or through the transparency portals- there are municipalities of which we do not have the information, despite the fact that due to their characteristics they should be included in the sample: Aguas de Valencia, Aguas de Albacete, Aguas de Alcalá, Aigües de Girona, Consorcio de Aguas de la Rioja, Empresa Mixta de Aguas de las Palmas, Aguas de Zaragoza (this case is peculiar as they are provided directly by the City Council), Aigües de Reus, EMMASA in Santa Cruz de Tenerife, EMATSA in Tarragona or Aguas de Telde.

But not only that, the lack of clear and homogeneous accounting criteria results in annual accounts with incomplete items and general annotations without detail to be able to compare between different companies. In addition, the lack of separate accounting for the activities carried out by a public utility company makes it difficult to treat them. The public company EMAYA (Empresa Municipal de Agua y Alcantarillado) in Palma de Mallorca is responsible, in addition to water and sewerage, for the selective collection of solid urban waste and street cleaning. However, there is no separate accounting for each activity, making it difficult to compare with other water-only companies.

In addition, the data in the annual accounts reported to the Ministry of Finance in the budgets of the local entities do not always coincide with the figures provided by the companies in the audit reports or their annual reports.

Despite the above, and given that the objective is to determine the efficiency of the participation of private capital in the provision of water supply services, data from the annual accounts -balance sheet and profit and loss account- for the last two years available were obtained for the companies providing the service in municipalities with more than 100,000 inhabitants and the provincial capitals of Spain, provided that they were public or mixed. The final sample is made up of 24 companies, 10 mixed and 14 public, 
supplying a total of 16.5 million people, employing more than 8,000 direct workers, distributing for supply more than 1,200 hm3 per year through $163,700 \mathrm{~km}$ of pipelines.

\begin{tabular}{|c|c|}
\hline Joint Ventures & Capital \\
\hline EMALGESA Algeciras & 51\% Ayto Algeciras, 49\% FCC Aqualia \\
\hline AMAEM Alicante & $51 \%$ Ayto. Alicante, $49 \%$ Hidraqua (Suez) \\
\hline Aigües de Barcelona & $70 \%$ AGBAR, $15 \%$ criteria Caixa, 15\% AMB \\
\hline Aigües d’Elx & $51 \%$ Ayto. Elche, $49 \%$ Hidraqua (Suez) \\
\hline EMASAGRA Granada & $51 \%$ Ayto. Granada, 49\% Hidralia (Suez) \\
\hline Aguas de Huelva & 51\% Ayto. Huelva, 49\% Hidralia (Suez) \\
\hline Aguas de León & 51\% Leon City Council, 49\% Aquona (Suez) \\
\hline EMUASA Murcia & 51\% Ayo. Murcia, 49\% Hidrogea (Suez) \\
\hline Aigües de Sabadell & 20\% Sabadell City Council, 78\% AGBAR (Suez) \\
\hline $\begin{array}{l}\text { TEIDAGUA San Cristóbal La } \\
\text { Laguna }\end{array}$ & $\begin{array}{l}\text { 40.26 \% San Cristóbal de La Laguna City Council, } 10.04 \% \\
\text { Tacoronte City Council, } 49.70 \text { \% Canaragua (SUEZ) }\end{array}$ \\
\hline \multicolumn{2}{|l|}{ Public Companies } \\
\hline Bilbao Water Consortium & $100 \%$ Public \\
\hline Aguas de Burgos & $100 \%$ municipal \\
\hline Aguas de Cádiz S.A. & $100 \%$ municipal \\
\hline EMACSA Córdoba & $100 \%$ municipal \\
\hline EMA Gijón & $100 \%$ municipal \\
\hline EMALCSA Coruña & $100 \%$ municipal \\
\hline Canal de Isabel II & 82.4 \% EP Canal Isabel II; 10 \% Madrid City Council; $7.6 \%$ other \\
\hline EMASA Malaga & $100 \%$ municipal \\
\hline Aigües de Mataró & $100 \%$ municipal \\
\hline Commonwealth of Pamplona & $100 \%$ Public \\
\hline Aguas del Añarbe, San Sebastian & $100 \%$ Public \\
\hline EMASESA Seville & $100 \%$ municipal (69.36\% Seville City Council, $30.64 \%$ other City \\
\hline AGUAVALL Valladolid & $100 \%$ municipal \\
\hline AMVISA Vitoria & $100 \%$ municipal \\
\hline
\end{tabular}

Source: Own elaboration

\section{METHODOLOGY}

In this phase of the work, in order to be able to draw preliminary conclusions, we have been establishing relationships between various items of the annual accounts, to observe their behavior. In a later phase, given the characteristics of the data, and always bearing in mind the limitations of a sample of 25 decision units, we will apply, together with other techniques, a data envelopment analysis (DEA). Introduced by Farrel (1957) and further developed by Charnes et al. (1978), DEA is the most widely used non-parametric method in empirical efficiency studies. It essentially calculates the economic efficiency of a given firm relative to the performance of other firms producing the same type of services, rather than on the basis of an idealized performance standard.

The ratios we are working with are mainly focused on the Net Turnover (NTI), obtaining the following preliminary results:

- Depreciation of fixed assets: public companies depreciate more than joint ventures

- Personnel costs: public companies pay more than joint ventures 
- Operating Results: public companies report higher results than joint ventures

- Equity: public companies are less productive (in terms of capital and reserves) than joint ventures.

Let's look at it graphically.

\section{Depreciation of Fixed Assets}

There is a notable difference in this item between joint ventures and public companies, which would be linked, firstly, to the lack of administrative obligation on how to compute amortizations - we should bear in mind that these services may use infrastructures built many years ago and that in any case they are renewed through maintenance expenses, without forgetting the variable of the years pending for the end of the concessions - and, secondly, to their impact on operating results. As this behavior is so generalized, it is worth paying more detailed attention to this accounting heading, which we will develop in later phases.

\section{FIGURE 1 \\ DEPRECIATION OF FIXED ASSETS / INCN}

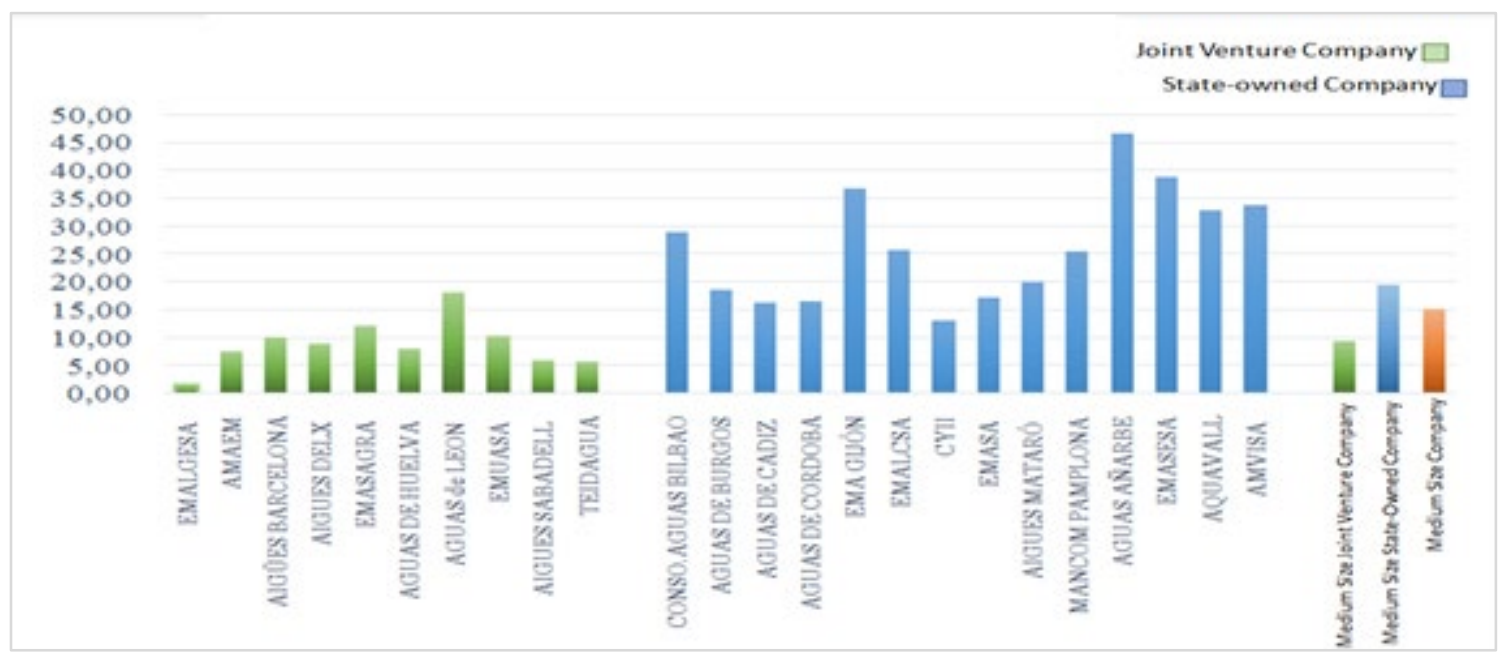

Source: Own elaboration

\section{Personnel Expenses Over INCN}

Personnel expenses are one of the most important items in the profit and loss account, representing an average of $21 \%$ of total turnover. When analyzing the figures, slight differences are observed between joint ventures and public companies, with this item being on average slightly higher in public companies.

While it is true that, comparatively with a previous work (Sevilla and Torregrosa, 2018), there are more differences between public and private companies than between public and mixed companies in the ratio of personnel expenses over INCN. 
FIGURE 2

\section{PERSONNEL EXPENSES / INCN}

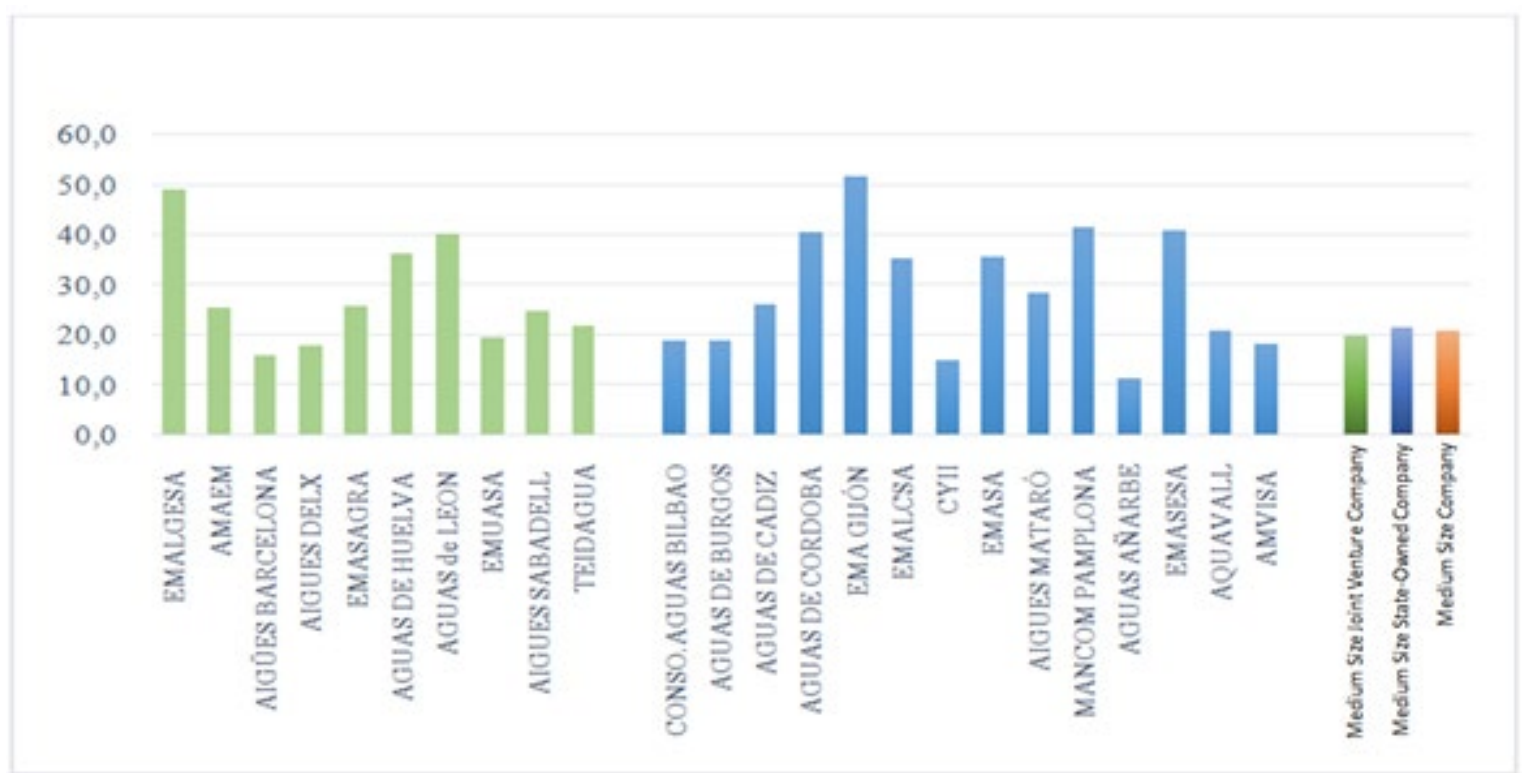

Source: Own elaboration

In terms of average cost per worker (number of workers and personnel costs), the figures are higher, on average, in joint ventures:

FIGURE 3

AVERAGE COST PER EMPLOYEE

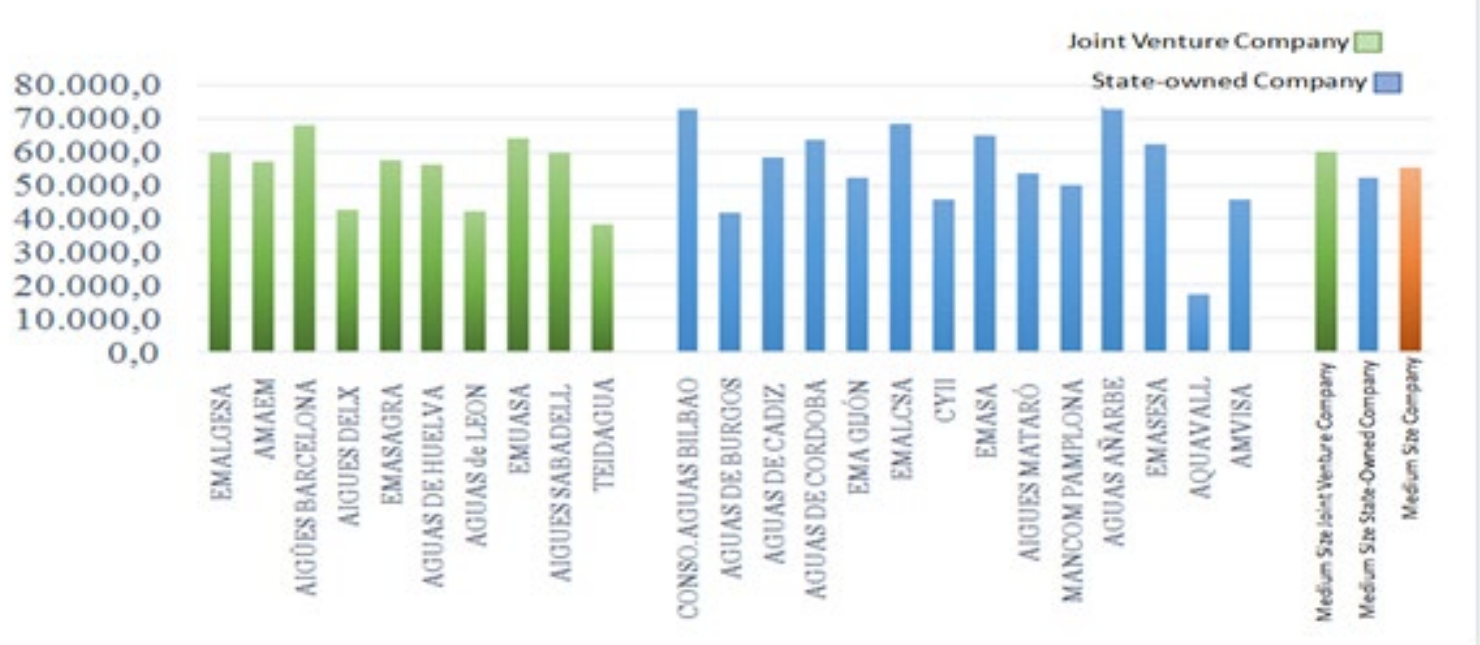

Source: Own elaboration

\section{Operating Income}

Our preliminary results, and in the absence of DEA analysis, seem to indicate that public utilities on average report higher results than joint ventures. Operating results (profits) are defined by the possibility of higher revenues - which in principle we link to tariffs - as well as to factor costs (water and energy supplies, personnel costs, etc.). Among other aspects that we are analyzing, one possible interpretation of 
these higher results in public companies is that if mixed companies were to show higher results, it would mean higher remuneration for the private partner, which is why, on occasions, they try to curb them. Public companies may show higher profits that could be used for reinvestment.

\section{FIGURE 4 \\ OPERATING INCOME / INCN}

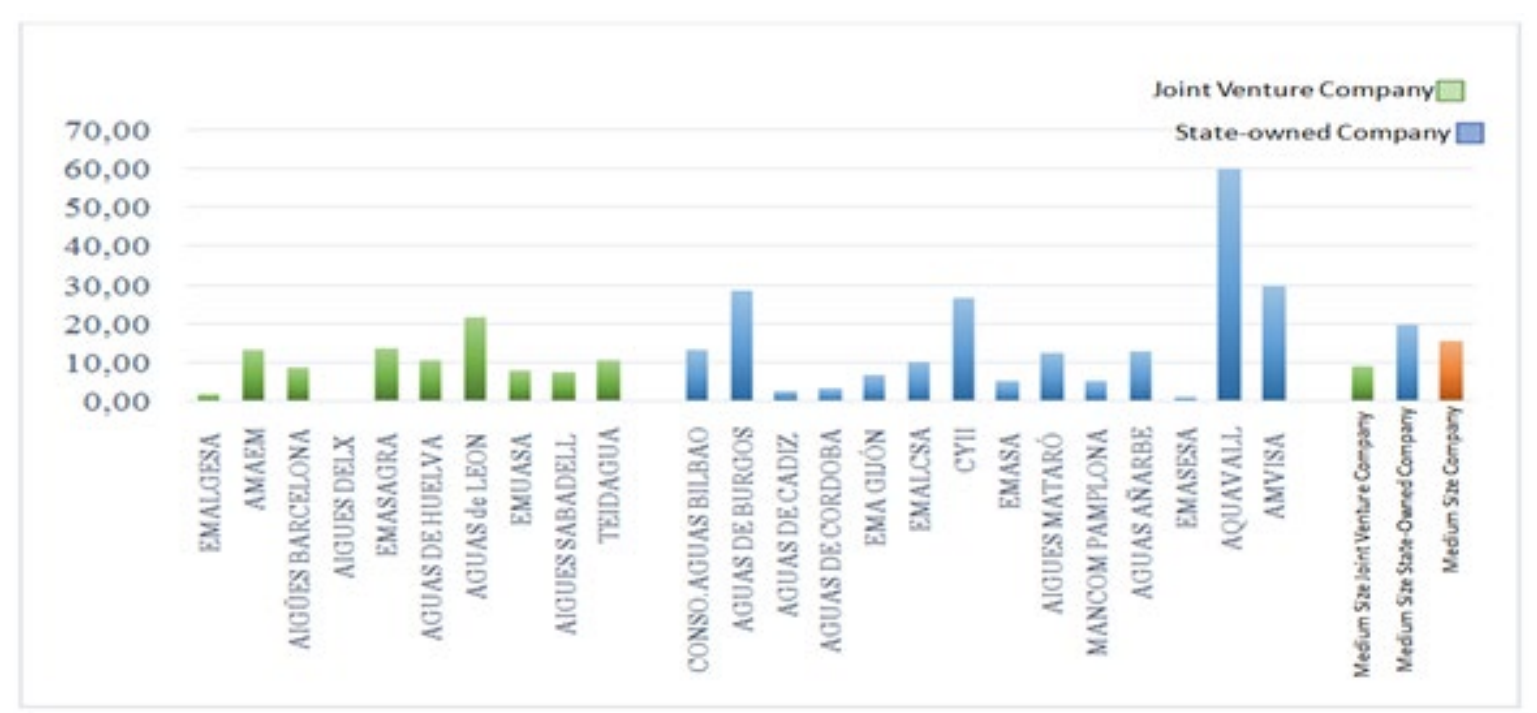

Source: Own elaboration

\section{Turnover, Population Served and Water Consumption}

The net turnover in relation to the number of inhabitants supplied relates the companies' revenues to the population, with joint ventures being above the average company. What this situation may indicate is that the tariffs applied by public companies are, on average, lower than those in which private capital participates.

\section{FIGURE 5}

\section{INCN 7 SUPPLIED POPULATION}

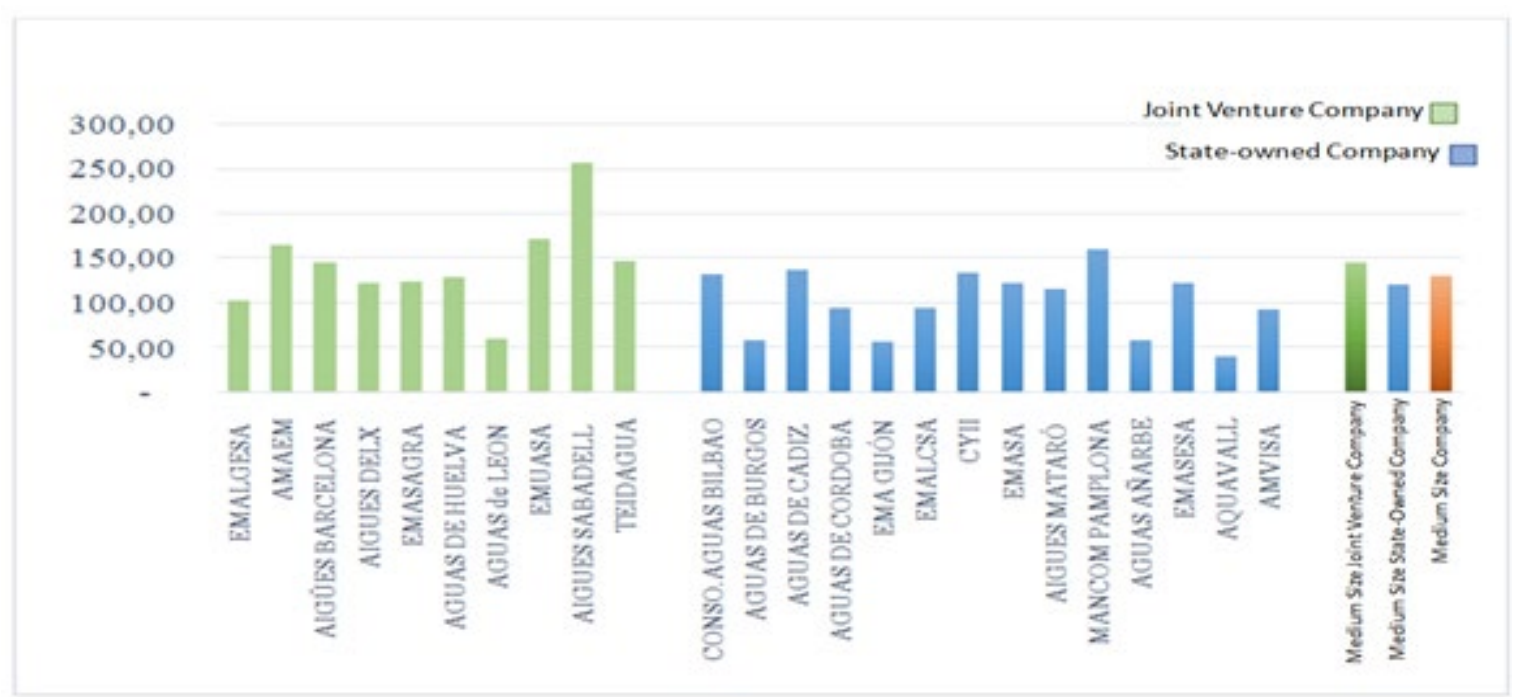

Source: Own elaboration 
With respect to the relationship between turnover and $\mathrm{m} 3$ served, it is the joint ventures that offer the best results. Efficiency with respect to water losses in the networks could be one of the reasons.

\section{FIGURE 6 \\ INCN / M3 INVOICED}

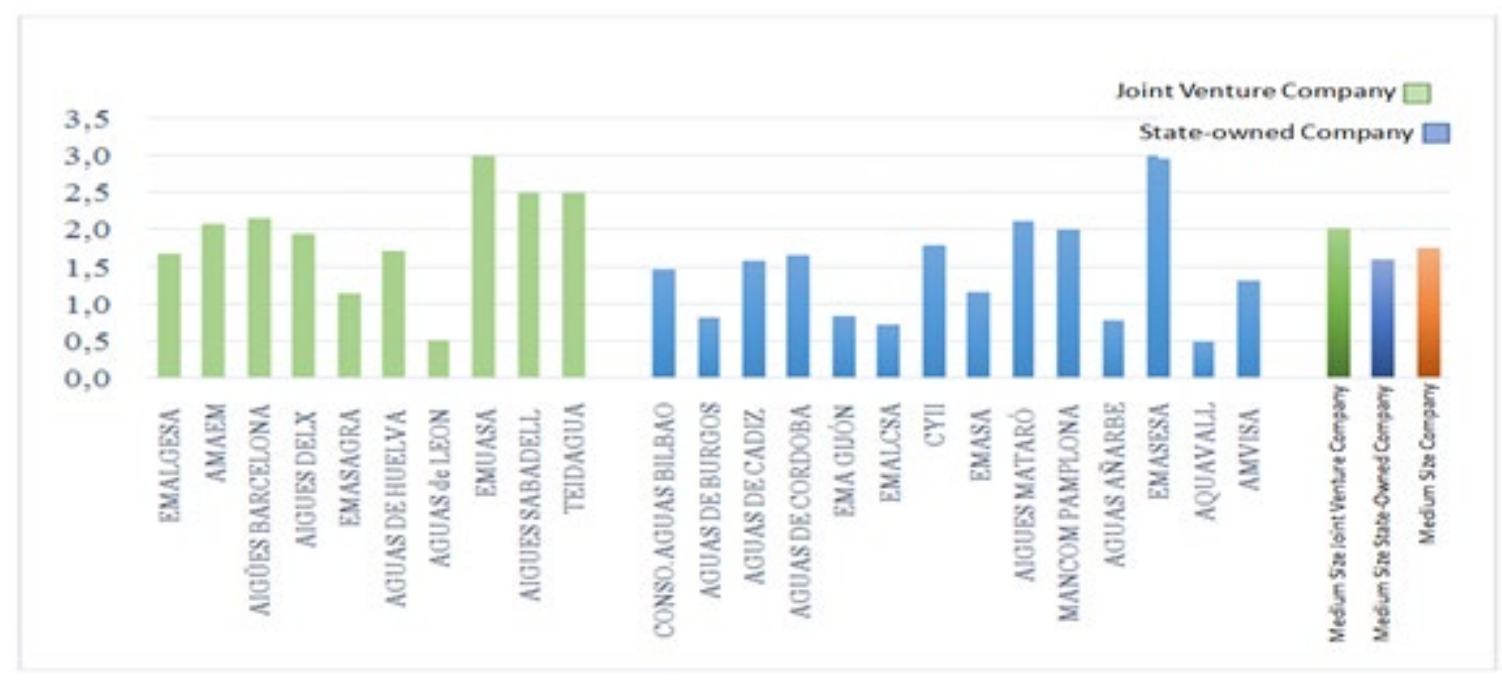

Source: Own elaboration

The ratio between supply costs and turnover is much lower in public utilities than in joint ventures. Although it would be very useful to know which of these costs are due to wholesale purchases of water (called adduction or "high water"), or the significant electricity costs to lift or boost the water in its different phases, practically no company differentiates these costs in the published documents. This makes it impossible to know how each of them influences the total costs.

FIGURE 7

SUPPLIES

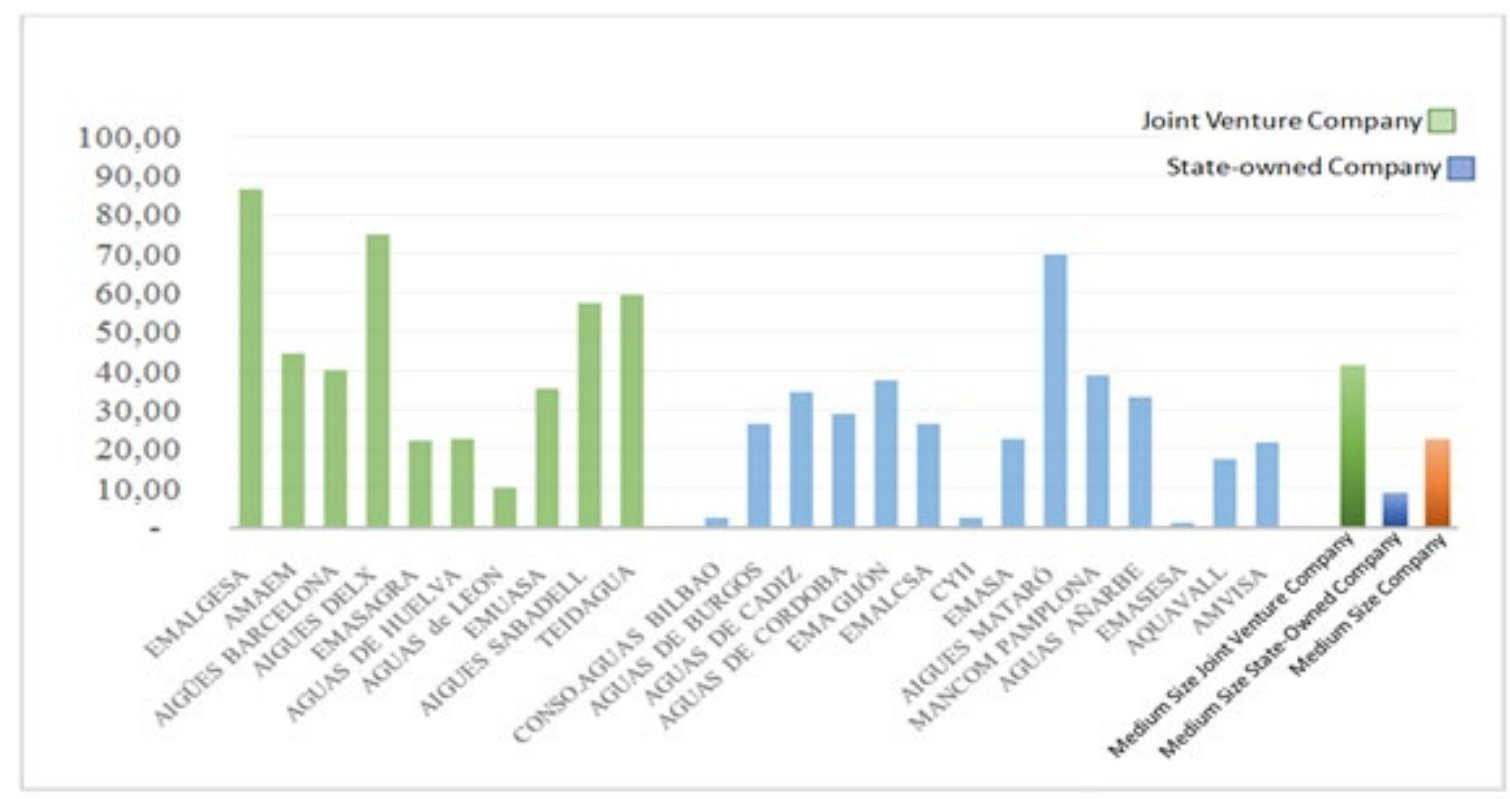

Source: Own elaboration 


\section{DISCUSSION / CONCLUSIONS}

In a rapidly changing world in which new challenges that we must face are appearing in a surprising way, the permanence of behaviors, attitudes and responses to these challenges that we theoretically considered to be periclitated is striking.

In recent years, water has been on the agendas of a large part of the planet (if not all of it), but the answers we are giving to the problem of its use and consumption are still entangled in policies set in the 60 s and 70 s of the twentieth century. It has already been mentioned that the debate between public or private provision of the service is still ongoing, since there are no conclusive general results that definitively support one or the other model.

Despite the limitations of the data, in the results of the water companies in Spain: is it all the same whether it is one or another company that provides the service? What should we base our advice to society and its leaders on? For one reason or another, the difficulty in obtaining the data, the incomplete information, different depending on the source, the lack of answers, ... are a sample of the obscurantism that now presides over the information on this sector and, in this way, justifies any type of action. In recent weeks, the extension for 20 years of a concession to a mixed company with a majority of private capital in exchange for an investment of 80 million euros in the construction of a network of storm water infrastructures was announced. No auction. Is it right to take a decision of this magnitude? Is there any procedure, apart from the legality of the agreement, to economically and financially evaluate this decision?

With the research project that we have been carrying out over the last few years at the University of Alicante, we intend to approach these realities from the modest field of applied economics, and to do so, there is nothing better than using the most rigorous information available. The results we have obtained, as we could expect, are not conclusive because we start from source data that, intentionally or not, do not allow us to draw definitive conclusions. But they do suggest to society and governments the need to change their neglect of statistical information (apart from taxation) if they want to improve public services, whether by using joint ventures, public companies or concessions to private companies.

Regardless of the transfer of the information handled for this work through a new model to determine the greater or lesser relevance of some or other companies, some partial results can be advanced:

- There are no radical differences between the two models. Either by imitation or by acquisition of equipment, public companies have been incorporating the advances of joint ventures (private) or other more advanced public companies, so that the differences are not enormous.

- Joint ventures make their equipment more profitable than public ones.

- Operating profits are higher in public utilities than in joint ventures. This important issue must be carefully analyzed as operating margins depend on tariff revenues and their linkage to costs. Is it in the interest of making a large profit that might require a tariff reduction?

- Labor costs and the number of workers present some relevant differences: While mixed companies have higher average salaries, public companies have a higher number of workers in their workforces.

Note to sources:

Mercantile Registry: Mercantile companies are obliged by the Royal Legislative Decree 1/2010, of July 2, which approves the revised text of the Capital Companies Act. (BOE 3-7-2010) to file their audited accounts annually with the Mercantile Registries where they are located. Both the Law and the Regulations of the Mercantile Registry (Royal Decree 1784/1996, of July 19, approving the Regulations of the Mercantile Registry (BOE 31-7-1996)) specify how both the Annual Accounts and the accompanying Annual Reports must be drafted.

Despite the requirements in their formulations, on many occasions we have found it difficult to access them because the companies themselves do not include them as documents in their transparency portals. For this reason, we have focused on those companies that do include them and those that have provided them by sending them. On the other hand, some of the problems that arise when analyzing these accounts are also those related to the detailing of the data and their aggregates and the possibilities of highlighting 
the same concepts in different sections. In these cases we have opted to go to the common aggregates and not to make any modifications on our part.

\section{ACKNOWLEDGEMENT}

Translated \& edited by American Publishing Services (https://americanpublishingservices.com/).

\section{ENDNOTES}

1. Palmira Bagán, a student of the GAP degree program, has also participated in this work through a collaboration grant with the Department of Applied Economic Analysis.

2. We have included in this group the Mancomunidades and Consorcios which, although they do not have the form of a trading company, also submit accounts to the Ministry of Finance.

\section{REFERENCES}

AEAS. (2018). Resultados del XV Estudio Nacional de Suministro de Agua Potable y Saneamiento en España. Asociación Española de Abastecimiento y Saneamiento y Asociación Española de Gestores de Abastecimiento de Agua Urbana.

Ameyaw, E.E., Chan, A.P.C., \& Owusu-Manu, D-G. (2017). A survey of critical success factors for attracting private sector participation in water supply projects in developing countries. Journal of Facilities Management, 15(1), 35-61. https://doi.org/10.1108/JFM-06-2016-0027

Arbués, F., Sanaú, J., \& Serrano, J.M. (2017). El precio del agua en las ciudades: Efectos del modelo gestion. Papeles de Economía, 1(153). Economía de las Ciudades.

Bel, G., \& Warner. (2008). Does Privatization of Solid Waste and Water Services Reduce Costs? A Review of Empirical Studies. Resources, Conservation \& Recycling, 52(12), 1337-48.

Bel, G. (2020). Public versus private water delivery, remunicipalization and water tariffs. Utilities Policy, $62(2020), 100982$.

Boggio, M. (2016). From public to mixed ownership in local public services provision: An empirical analysis. Local Government Studies, 42(3), 420-440. DOI: 10.1080/03003930.2016.1146138

Braadbaart, O. (2002). Private versus public provision of water services: Does ownership matter for utility efficiency? Journal of Water Supply: Research and Technology-Aqua, 51(7), 375-388. https://doi.org/10.2166/aqua.2002.0034

Byrnes, J., Crase, L., Dollery, B., \& Villano, R. (2010). The relative economic efficiency of urban water utilities in regional New South Wales and Victoria. Resource and Energy Economics, 32, 439455.

Charnes, A., Cooper, W.W., \& Rhodes, E. (1978). Measuring the efficiency of decision making units. Eur. J. Oper. Res., 2, 429-444.

Comendeiro-Maaløe, M., Ridao-Lópeza, M., Gorgemans, S., \& Bernal-Delgado, E. (2019). Public-private partnerships in the Spanish National Health System: The reversion of the Alzira model. Health Policy, 123(2019), 408-411.

Dassler, T., Parker, D., \& Saal, D.S. (2006). Methods and trends of performance benchmarking in UK utility regulation. Utility Policies, 14, 166-174.

Devkar, G., Mahalingam, A., Deep, A., \& Thillairajanb, A. (2013). Impact of Private Sector Participation on access and quality in provision of electricity, telecom and water services in developing countries: A systematic review. Utilities Policy, 27, 65-81.

Estache, A., \& Rossi, M.A. (2002). How different is the efficiency of public and private water companies in Asia? (English). Washington, D.C.: World Bank Group.

Farrell, M. (1957). The measurement of productive efficiency. J. R. Stat. Soc., 3, 253-290. 
Ferreira, D.C., \& Marques, R.C. (2020). Public-private partnerships in health care services: Do they outperform public hospitals regarding quality and access? Evidence from Portugal. SocioEconomic Planning Sciences, in press. https://doi.org/10.1016/j.seps.2020.100798

Frone, S., \& Frone, D.F. (2013). Public-Private Partnerships as Mechanisms for Risk Management in the Water Sector. Scientific Papers. Management, Economic Engineering in Agriculture and Rural Development, 13(3), 103-110.

González-Gómez, F., \& García-Rubio, M. (2018). Prices and ownership in the water urban supply: A critical review. Urban Water Journal, 15(3), 259-268.

Hall, D., \& Lobina, E. (2004). Private and public interests in water and energy. Natural Resources Forum, 28(4), 268-277.

Hammami M., Ruhashyankiko J., \& Yehoue E. (1999). Determinants of Public Private Partnerships in Infrastructure. International Monetary Fund Working Paper WP/06/99.

Hodge, G., \& Greve, C. (2018). Contemporary public-private partnership: Towards a global research agenda. Financial Acc \& Man, (34), 3-16.

Hodge, G., Greve, C., \& Boardman, A.E. (2012). International Handbook on Public-Private Partnerships. Edward Elgar. Cheltenham, UK. Northampton, MA, USA.

Jensen, O. (2017). Public-private partnerships for water in Asia: A review of two decades of experience. International Journal of Water Resources Development, 33(1), 4-30. DOI:10.1080/07900627.2015.1121136

Kirkpatrick, C., Parker, D., \& Zhang, Y.F (2006). State versus private sector provision of water services in Africa: An empirical analysis. The World Bank Economic Review, 20(1), 143-187.

Lee, H., Junga, E.Y., \& Lee, J.D. (2019). Public-private co-evolution and niche development by technology transfer: A case study of state-led electricity system transition in South Korea. Energy Research \& Social Science, 49, 103-113.

Lobina, E. (2013). Remediable institutional alignment and water service reform: Beyond rational choice. Int J Water Gov., l(132), 109.

Marques, R.C., \& Simões, P. (2020). Revisiting the Comparison of Public and Private Water Service Provision: An Empirical Study in Portugal. Water, 12, 1477.

Mckee, M., Nigel, E., \& Rifat, A. (2006, November) Public-Private Partnerships for Hospitals. Bulletin of the World Health Organization, 84(11).

Ministerio De Hacienda. (various years). Publication of information on budgets by Local Entities. Retrieved June 2020, from https://www.hacienda.gob.es/es-EN/Areas\%20Tematicas/ Administracion\%20Electronica/OVEELL/Paginas/PublicacionPresupu estosEELL.aspx

Moore, M.A., Broadman, A.E., \& Vining, A. (2017). Analyzing risk in PPP provision of utility services: A social welfare perspective. Utilities Policy, 48(2017), 210-218.

OHCHR. (2011). El derecho al agua. Folleto informative No. 35 Oficina del Alto Comisionado de las Naciones Unidas para los Derechos Humanos, Ginbera, Suiza.

Peda, P., \& Vinnari, E. (2020). The discursive legitimation of profit in public-private service delivery. Critical Perspectives on Accounting, 69, 102088. https://doi.org/10.1016/j.cpa.2019.06.002

Rebollo Fuente, A. (2007). APPs institucionales, financiamiento de infraestructuras y contabilidad pública. Reflexiones, 2, 61-122.

Ridao, J. (2012). La colaboración público-privada en la provision de infraestructuras de servicio público. Revista Catalana de dret Public, 45(2012), 191-214.

Romano, G., \& Guerrini, A. (2011). Measuring and comparing the efficiency of water utility companies: A data envelopment analysis approach. Utilities Policy, 19, 202-209.

Ruiz-Villaverde, A., \& García-Rubio, M.A. (2017). Public Participation in European Water Management: From Theory to Practice. Water Resour Manage, 31, 2479-2495. https://doi.org/10.1007/s11269$016-1355-1$

Sanaú, J. (2017). Los aspectos sociales en la gestion pública o privada del servicio urbano de aguas. El Cronistas del Estado Social y Democrático de Derecho, 69, 50-59. 
Sanchez-Gómez, F., \& López-Parra, J. (2017). Cooperación público-privada en la protección de infraestructuras críticas. Cuadernos de Estrategia, 185(2017), 171-216.

Schouten, M., \& Van Dijk, M.P. (2008). Private sector involvement according to European water liberalisation scenarios. International Journal of Water (IJW), 4(3/4), 180-196.

Sevilla, M., \& Torregrosa, T. (2018). La gestión del agua en las ciudades españolas: úgestión pública o gestión privada? Dejemos hablar a las cifras. Comunicación presentada al X Congreso Ibérico de Gestión Planificación del Agua Coimbra.

Suárez-Varela, M., García-Valiñas, M.A., González-Gómez, F., \& Picazo-Tadeo, A. (2016). Ownership and Performance in Water Services Revisited: Does Private Management Really Outperform Public? Water Resour Manage, 31, 2355- 2373. doi: 10.1007/s11269-016-1495-3

Thanassoulis, E. (2000). The use of data envelopment analysis in the regulation of UK water utilities: Water distribution. European Journal of Operational Research, 126, 436-453.

The World Bank. (2020). Private Participation in Infrastructure (PPI) 2019. Annual Report. IBR, IDA. Washington DC.

The World Bank. (2012). Public-Private Partnerships. Reference guide 1.0. Washington DC.

Troesken, W. (2001). Race, disease, and the provision of water in American Cities, 1889-1921. J. Econ. Hist., 61(3), 750-776.

Vagliasindi, M. (2013). Revisiting Public-Private Partnerships in the Power Sector. A World Bank Study, The World Bank, Washington D.C. http://dx.doi.org/10.1596/978-0-8213-9762-6

Voorn, B., Van Genugten, M.L., \& Van Thiel, S. (2017). The efficiency and effectiveness of municipally owned corporations: A systematic review. Local Government Studies, 43(5), 820-841. doi:10.1080/03003930.2017.1319360

Willig, R. (1993). Public versus Regulated Private Enterprise. The World Bank Economic Review, 7(1), 155-170. https://doi.org/10.1093/wber/7.suppl_1.155

Wollmann, H., \& Marcou, G. (2010). The Provision of Public Services in Europe: Between State, Local Government and Market. Edward Elgar Publishing - Business \& Economics - 288 pages. 